\title{
Effect of topical $0.5 \%$ povidone-iodine compared to $5 \%$ natamycin in fungal keratitis caused by Fusarium solani in a rabbit model: a pilot study
}

\author{
Efeito tópico de iodo-povidona 0,5\% comparado com natamicina 5\% \\ em ceratites fúngicas causadas por Fusarium solani \\ em um modelo animal de coelhos: estudo piloto
}

\author{
Lauro Augusto de Oliveira ${ }^{1}$ \\ Thales Takeo Takata ${ }^{2}$ \\ Alvio Isao Shiguematsu ${ }^{3}$ \\ Luiz Alberto Soares Melo Júnior ${ }^{4}$ \\ Olga Fischman Gompert $z^{5}$ \\ Luciene Barbosa de Sousa ${ }^{6}$ \\ Mark J.Mannis ${ }^{7}$
}

\footnotetext{
This study was funded in part by a generous grant to UC Davis Ophthalmology from Research to Prevent Blindness, Inc. New York, NY and by CAPES, Ministry of Education, Brazil.

M.D., Universidade Federal de São Paulo - UNIFESP São Paulo (SP) - Brazil; University of California - Davis.

M.D., UNIFESP - São Paulo (SP) - Brazil.

${ }^{3}$ M.D., UNIFESP - São Paulo (SP) - Brazil.

${ }^{4}$ M.D., UNIFESP - São Paulo (SP) - Brazil.

M.D., UNIFESP - São Paulo (SP) - Brazil.

${ }^{6}$ M.D., UNIFESP - São Paulo (SP) - Brazil.

M.D., University of California - Davis.

Corresponding author: Lauro Augusto de Oliveira. Avenida 11 de Junho, 685 - Apto. 52 - São Paulo (SP) Zip Code 04041-052

E-mail: laopadilha@terra.com.br

Recebido para publicação em 15.03.2008

Aprovado em 30.10.2008
}

\begin{tabular}{l} 
ABSTRACT \\
\hline Purpose: To evaluate the efficacy of topical administration of $0.5 \%$ \\
povidone-iodine in experimental Fusarium solani keratitis in rabbits. \\
Methods: Fungal keratitis caused by Fusarium solani was induced in the \\
right eye of 24 New Zealand rabbits. The rabbits were randomly divided \\
into 3 different treatment groups: Group I (povidone-iodine) - treated with \\
topical 0.5\% povidone-iodine; Group II (natamycin) - treated with topical \\
5\% natamycin; and Group III (control) - treated with topical saline solution. \\
In all groups the rabbits were treated for three days and then sacrificed. The \\
corneas were excised, macerated and immersed in 10 mL BHI. Culture \\
samples were plated daily on Sabouraud's agar for 7 days, and the number \\
of colony-forming units (CFU) was counted. The rabbits were clinically \\
evaluated during the treatment period. Results: The povidone-iodine and \\
natamycin groups demonstrated better efficacy than the control group \\
based on the number of rabbits with no colonies growing. However, there \\
were no statistically significant differences between the three groups \\
when the number of CFU was analyzed (p>0.05). Conclusion: Our study \\
demonstrates important methodological considerations in the use of in \\
vivo animal models for the testing of antifungal agents. Using this sample \\
size and methodology of counting CFU, topical $0.5 \%$ povidone-iodine \\
demonstrated no benefit in the treatment of experimental Fusarium solani \\
when compared with topical $5 \%$ natamycin.
\end{tabular}

Keywords: Keratitis/microbiology; Povidone-iodine/administration \& dosage; Povidoneiodine/therapeutic use; Fusarium; Natamycin/administration \& dosage; Natamycin/therapeutic use; Eye infections, fungal/drug therapy; Antifungal agents/administration \& dosage; Antifungal agents/therapeutic use

\section{INTRODUCTION}

Among suppurative corneal ulcerations, fungal keratitis is responsible for significant ocular morbidity and blindness, primarily in the developing world. Its incidence is variable, but it is clearly higher in regions with a warm, humid climate and/or in an agricultural economy ${ }^{(1)}$. Studies from different continents identified fungi in $6 \%$ to $53 \%$ of cases of suppurative keratitis ${ }^{(2-3)}$. Filamentous fungi are responsible for the majority of these cases ${ }^{(4)}$. Höfling-Lima et al. ${ }^{(5)}$ cited filamentous fungi as responsible for $79 \%$ of fungal keratitis and showed that the genus Fusarium is responsible for $59 \%$ of the fungal keratitis in patients of the Federal University of São Paulo. 
The key elements in successful treatment of this condition in a manner which spares vision are early diagnosis, timely identification of the pathogen, and application of effective antifungal drugs. While early diagnosis and identification of pathogens is generally straightforward, the therapy for fungal keratitis is restricted by a limited choice of effective antifungal drugs for topical administration.

The polyene, natamycin (pimaricin), has been recommended at a concentration of $5 \%$ as the topical drug of choice for first line treatment of filamentous fungal keratitis ${ }^{(6-7)}$. In recent years, azole compounds have demonstrated promise in the treatment of fungal keratitis. Prajna et al. ${ }^{(8)}$ reported that a $2 \%$ preparation of econazole for topical application was as effective as 5\% natamycin in the management of filamentous fungal keratitis. Kalavathy et al. ${ }^{(9)}$ compared topical $1 \%$ itraconazole with $5 \%$ natamycin and reported that natamycin should continue to be the treatment of choice for filamentous fungal keratitis. However, in many developing nations, natamycin and azole compounds are not readily available or affordable.

Povidone-iodine has been used for many years as an effective broad-spectrum disinfectant in ophthalmic surgeries ${ }^{(10)}$. The solution is inexpensive and widely available. Povidoneiodine is a complex of polyvinylpyrrolidone and iodine. Its chemistry is only partially understood and has been subject of several reviews. Several studies have demonstrated its effectiveness against bacteria ${ }^{(11)}$. It is also effective against viruses and fungi(2).

We sought to evaluate the potential clinical efficacy of topical $0.5 \%$ povidone-iodine eyedrop preparation by comparing it with a standard therapeutic regimen with topical 5\% natamycin for Fusarium solani fungal keratitis in a rabbit model.

\section{METHODS}

We performed an experimental, randomized, controlled study in a rabbit model. Permission for the experimental study was obtained from the Ethics Committee of the Federal University of São Paulo, and we strictly adhered to the experimental rules set forth in the ARVO resolution on animal experimentation.

A strain of Fusarium solani (IMI 314228, International Mycological Institute, Surrey, UK) was grown on potatodextrose agar slants at $35^{\circ} \mathrm{C}$ for the first 48 hours and at $25^{\circ} \mathrm{C}$ until day 7. The formed colonies were covered with $2 \mathrm{~mL}$ sterile $0.9 \%$ saline, and suspended by gently probing them with the tip of a Pasteur pipette. The resulting mixture of conidia, hyphal fragments and agar particles was transferred to a sterile test tube. Heavy particles were allowed to settle for 5 minutes, and the upper homogeneous suspension was collected with a micropipette, transferred to another tube and mixed in a vortex for 15 seconds. The density of the conidial suspension was read in a spectrophotometer and adjusted to an optical density range of 0.15 to 0.17 , which corresponds to $0.4 \times 10^{6}$ to $0.5 \mathrm{x}$ $10^{6} \mathrm{CFU} / \mathrm{mL}$. Inoculum size was also checked by plating $10 \mu \mathrm{L}$ of a 1:100 dilution of the suspension on Sabouraud agar plates and by counting the conidia in a Neubauer chamber.

We induced Fusarium solani keratitis in the right eye of 24 adult male New Zealand rabbits (1.4-2.6 kg in weight). Prior to the inoculation, the eyes received 5 daily subconjunctival injections of $0.2 \mathrm{~mL} 0.4 \%$ dexamethasone sodium phosphate, under topical anesthesia (proparacaine). Inoculation was performed on the last day of this preparation.

Animals were anesthetized with intramuscular ketamine hydrochloride (35-50 mg/kg), xylazine hydrochloride $(5-7.5 \mathrm{mg} / \mathrm{kg}$ ), and with topical $0.5 \%$ proparacaine hydrochloride drops. Under the operating microscope, the eye was gently proptosed and fixated. A temporal vertical incision, $2 \mathrm{~mm}$ in width and $250 \mu \mathrm{m}$ in depth, was made $2 \mathrm{~mm}$ from the center of the cornea with a diamond knife. The blunt needle of a microsyringe (model 80300, Hamilton Company, Reno, NV, USA) was advanced through the previous incision and $10 \mu \mathrm{L}$ of the inoculum were injected into the corneal stroma. Five days after inoculation, we verified the presence of a corneal infiltrate (Figure 1) (infiltrate $\geq 2 \mathrm{~mm}$ ), and we divided the animals randomly into 3 treatment groups: Gr.I: treated with topical $0.5 \%$ povidone-iodine hourly $(7 \mathrm{am}-11 \mathrm{pm})$ for three days; Gr.II: treated with topical $5 \%$ natamycin hourly $(7 \mathrm{am}-11 \mathrm{pm})$ for three days; and Gr.III: treated with topical normal saline hourly (7am - 11pm) for three days (control). All animals underwent corneal scraping for debridement of the epithelium and necrotic tissue overlying the infiltrate to allow for better penetration of the topical antimicrobial drops before initiating the treatment. The three different drugs were prepared under sterile conditions by the same pharmaceutical company (Ophtalmos Fórmulas Oficinais Ltda., São Paulo, Brasil) using identical diluents. There were no preservatives in any of the three preparations. Prophylactic moxifloxacin (Vigamox ${ }^{\circledR}$, Alcon, Fort Worth, TX, USA) drops were used every 6 hours on the right eye of all animals. During the treatment, we evaluated the rabbits daily with the slit lamp, and clinical features were scored. We considered the size and depth of the infiltrate, the

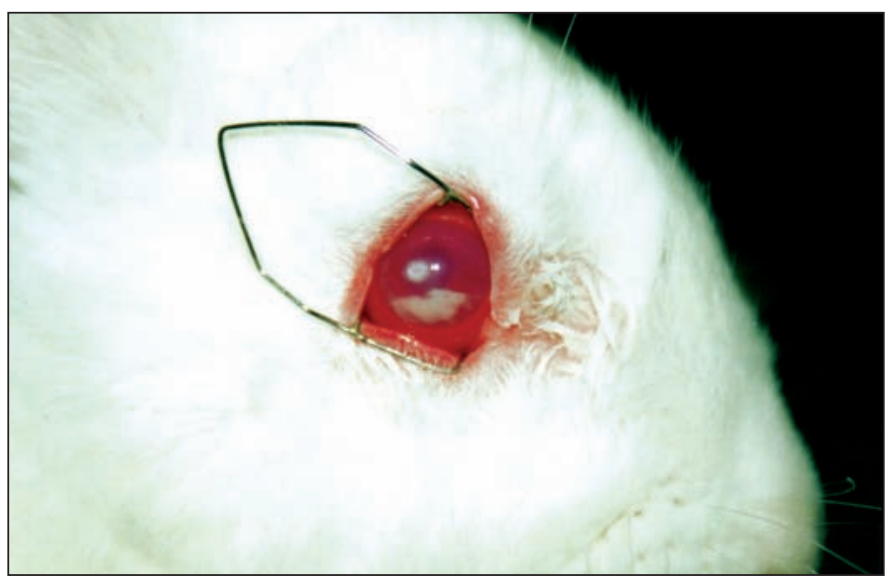

Figure 1 - Infected rabbit. $2 \mathrm{~mm} \times 2.5 \mathrm{~mm}$ central corneal infiltrate with hypopyon in the anterior chamber. 
growth of new vessels into the cornea, conjunctival injection, hypopyon, and discharge.

The day after conclusion of the treatment period, all rabbits were anesthetized with intramuscular ketamine hydrochloride $(35-50 \mathrm{mg} / \mathrm{kg})$ and xylazine hydrochloride $(5-7.5 \mathrm{mg} / \mathrm{kg}$ ), and were sacrificed with intravenous sodium pentobarbital $(150 \mathrm{mg} / \mathrm{kg})$. The right cornea of each animal was trephined, thoroughly washed with sterile balanced salt solution, macerated, and immersed in $10 \mathrm{~mL}$ BHI with gentamicin $(50 \mathrm{mg} / \mathrm{L})$ and chloramphenicol $(40 \mathrm{mg} / \mathrm{L})$. All surgical instruments were utilized on a single use base to avoid cross contamination.

Immediately after incubation, the test tubes contents were homogenized for 15 seconds and allowed to settle for 15 minutes. These solutions were diluted to $1 / 10$ and to $1 / 100$. A $10 \mu \mathrm{L}$ aliquot of the upper homogeneous suspension of each solution and its dilutions were plated on Sabouraud's agar and kept at $25^{\circ} \mathrm{C}$. This procedure was repeated every 24 hours for 7 days. The number of CFU was counted for 5 days after each seeding (total of seven seeding days). We established $100 \mathrm{CFU}$ as the maximum growth. We considered days 1,4 , and 7 of seeding for analyzing the CFU at the standard solution and 1/10 diluted solution. For the 1/100 diluted solution, we considered days 1 and 7 of seeding. The comparisons of CFU counts for the three study groups were performed using the Kruskal-Wallis test.

\section{RESULTS}

We found no statistically significant difference in clinical appearance between the three groups after treatment. All groups had clinically indistinguishable disease during the treatment period and on the day of sacrifice.

Groups I and II, 0.5\% povidone-iodine and 5\% natamycin respectively, demonstrated better efficacy than Gr. III (control) when comparing the number of rabbits in which there were no colonies growing. Four rabbits in Gr.I, 5 rabbits in Gr.II, and 3 rabbits in Gr.III demonstrated no colony growth. However, the confidence intervals between the three groups overlapped, suggesting that there was no statistically significant difference between them (Graph 1).

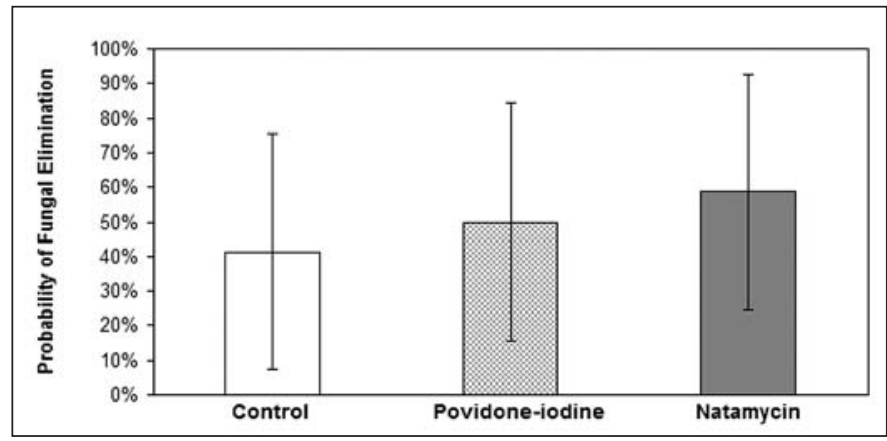

Graph 1 - Confidence intervals for the three treatment groups of funga keratitis due to Fusarium solani (intervals at $95 \%$ confidence level)
On days 1, 4, and 7 after incubation in BHI, samples were plated on Sabouraud agar and were counted on days 1 through 5. The standard solution (Table 1) and the 1/10 diluted solution (data not shown) demonstrated no statistical difference in the number of CFU between the 3 groups. Likewise, the 1/100 diluted solution demonstrated no statistical difference on days 1 and 7 after incubation in BHI, considering counting days 1 through 5 (Table 1).

\section{DISCUSSION}

Povidone-iodine has a broad spectrum of action, is cost effective, and has been used for preoperative antibiotic prophylaxis ${ }^{(10)}$. Its efficacy against Fusarium solani has been demonstrated in vitro by Martin et al. ${ }^{(2)}$, as well as in vivo ${ }^{(12)}$. White et al. ${ }^{(12)}$ reported that $1 \%$ povidone-iodine led to a significant reduction in the duration of experimentally induced disease with Aspergillus niger, in rabbits, without notable irritation. Because of its effectiveness against filamentous fungi in vitro as well as in vivo, we evaluated its benefits in a rabbit model of Fusarium solani keratitis.

Our study demonstrated no clinical difference between the three groups during the treatment period. It is possible that subconjunctival injection of corticosteroids may have partially suppressed the ocular inflammation and the rabbits got infected in such a similar situation, that no difference in clinical response could be determined during the three treatment days. Fiscella et al. ${ }^{(13)}$ reported the same lack of difference in clinical features for 10 days after corticosteroid administration in an experimental Fusarium keratomycosis. O'Day et al. ${ }^{(14)}$ noted that the use of glucocorticoids, usually given subconjunctivally, alters the course of disease and facilitates the establishment of infection. When corticoids are given, the fungal burden remains stable longer and the inflammatory response in the cornea is worsened ${ }^{(15)}$. It is also noted that the usual effective duration of this rabbit model of filamentous keratitis is about 5-10 days ${ }^{(14,16)}$. Moreover, three days of clinical evaluation is a very short period of time to discern significant clinical differences between the groups when dealing with fungal infection. On the other hand, this finding suggests that the methodology used to infect the animals worked similarly in all groups. Evaluation of clinical scores was, therefore, not considered a reliable measure of active infection in this study.

There was no statistical significance when we compared the number of rabbits in which there were no colonies growing. The confidence intervals between the three groups overlapped. If we assume repeatability of the point estimates, a calculation would give an appropriate sample size for future experiments. However, we did not have a normal distribution in our study, and consequently, it is difficult to determine the adequate sample size for future experiments. It is impressive that in 3 rabbits in the control group the infection resolved with no treatment. This reflects the strong inflammatory res- 


\begin{tabular}{|c|c|c|c|c|c|c|c|c|c|c|c|c|}
\hline & \multirow[b]{3}{*}{$\begin{array}{l}\text { Incubation } \\
\text { time in } \\
\mathrm{BHI}\end{array}$} & \multirow[b]{3}{*}{ Group } & \multicolumn{10}{|c|}{ Days in Petri dish } \\
\hline & & & 1 Day & & 2 Days & & 3 Days & & 4 Days & & 5 Days & \\
\hline & & & $\begin{array}{c}\text { CFU } \\
\text { Median } \\
(\text { min-max })\end{array}$ & $P$ & $\begin{array}{c}\text { CFU } \\
\text { Median } \\
\text { (min-max) }\end{array}$ & $P$ & $\begin{array}{c}\text { CFU } \\
\text { Median } \\
\text { (min-max) }\end{array}$ & $P$ & $\begin{array}{c}\text { CFU } \\
\text { Median } \\
\text { (min-max) }\end{array}$ & $P$ & $\begin{array}{c}\text { CFU } \\
\text { Median } \\
\text { (min-max) }\end{array}$ & $P$ \\
\hline SS & 1 Day & $\begin{array}{l}\text { Control } \\
\text { Povidone } \\
\text { Natamycin }\end{array}$ & $\begin{array}{l}0(0-0) \\
0(0-0) \\
0(0-0)\end{array}$ & 1.00 & $\begin{array}{l}0(0-0) \\
0(0-0) \\
0(0-0)\end{array}$ & 1.00 & $\begin{array}{l}0(0-0) \\
0(0-0) \\
0(0-0)\end{array}$ & 1.00 & $\begin{array}{l}0(0-0) \\
0(0-0) \\
0(0-0)\end{array}$ & 1.00 & $\begin{array}{l}0(0-0) \\
0(0-0) \\
0(0-0)\end{array}$ & 1.00 \\
\hline SS & 4 Days & $\begin{array}{l}\text { Control } \\
\text { Povidone } \\
\text { Natamycin }\end{array}$ & $\begin{array}{r}10(0-38) \\
0(0-49) \\
0(0-86)\end{array}$ & 0.38 & $\begin{array}{r}64.5(0->100) \\
0(0->100) \\
0(0->100)\end{array}$ & 0.62 & $\begin{array}{r}69.5(0->100) \\
0(0->100) \\
0(0->100)\end{array}$ & 0.73 & $\begin{array}{r}72.5(0->100) \\
0(0->100) \\
0(0->100)\end{array}$ & 0.65 & $\begin{array}{r}72.5(0->100) \\
0(0->100) \\
0(0->100)\end{array}$ & 0.65 \\
\hline SS & 7 Days & $\begin{array}{l}\text { Control } \\
\text { Povidone } \\
\text { Natamycin }\end{array}$ & $\begin{array}{l}3(0-18) \\
0(0-13) \\
0(0-12)\end{array}$ & 0.53 & $\begin{array}{r}>100(0->100) \\
50(0->100) \\
0(0->100)\end{array}$ & 0.70 & $\begin{array}{r}>100(0->100) \\
50(0->100) \\
0(0->100)\end{array}$ & 0.70 & $\begin{array}{r}>100(0->100) \\
50(0->100) \\
1(0->100)\end{array}$ & 0.79 & $\begin{array}{r}>100(0->100) \\
50(0->100) \\
1(0->100)\end{array}$ & 0.79 \\
\hline $1 / 100$ & 1 Day & $\begin{array}{l}\text { Control } \\
\text { Povidone } \\
\text { Natamycin }\end{array}$ & $\begin{array}{l}0(0-0) \\
0(0-0) \\
0(0-0)\end{array}$ & 1.00 & $\begin{array}{l}0(0-0) \\
0(0-0) \\
0(0-0)\end{array}$ & 1.00 & $\begin{array}{l}0(0-0) \\
0(0-0) \\
0(0-0)\end{array}$ & 1.00 & $\begin{array}{l}0(0-0) \\
0(0-0) \\
0(0-0)\end{array}$ & 1.00 & $\begin{array}{l}0(0-0) \\
0(0-0) \\
0(0-0)\end{array}$ & 1.00 \\
\hline $1 / 100$ & 7 Days & $\begin{array}{l}\text { Control } \\
\text { Povidone } \\
\text { Natamycin }\end{array}$ & $\begin{array}{l}0(0-0) \\
0(0-0) \\
0(0-5)\end{array}$ & 0.89 & $\begin{aligned} 9 & (0-19) \\
0.5 & (0-15) \\
0 & (0->100)\end{aligned}$ & 0.77 & $\begin{aligned} 11 & (0-24) \\
0.5 & (0-20) \\
0 & (0->100)\end{aligned}$ & 0.75 & $\begin{aligned} 11.5 & (0-24) \\
0.5 & (0-20) \\
0 & (0->100)\end{aligned}$ & 0.75 & $\begin{aligned} & 11.5(0-24) \\
& 0.5(0-20) \\
& 0(0->100)\end{aligned}$ & 0.77 \\
\hline
\end{tabular}

ponse presented by rabbits to infectious agents. In some cases demonstrating healing in a period of time up to 8 days after inoculation, even with subconjunctival corticosteroid administration previous to inoculation ${ }^{(17)}$.

Another limitation in our study was fixing the maximum number of CFU at 100 . We used that number since in our previous pilot study, the colonies were confluent and became somewhat indistinct one from another. Preestablishing that number fixed the limit for statistical analysis for all groups; in some cases the CFU would clearly be higher than that, if it had been possible to count the colonies further. For example, when we observe the control group on the $7^{\text {th }}$ day of incubation in $\mathrm{BHI}$, and on the $2^{\text {nd }}$ day of colony counting, the number of colonies was higher than 100 (Table 1). It is evident that this number would be higher than that on the $5^{\text {th }}$ day of colony counting. Establishing $100 \mathrm{CFU}$ as the maximum limit for all groups rendered the statistical analysis limited. We recognized the problem with counting more than 100 colonies per plate in previous pilot studies. An alternative solution was to dilute the standard solution to $1 / 10$ and $1 / 100$. However, analyzing diluted solutions did not demonstrate statistical significance between the groups in any of the evaluated incubation and counting days. We plated the standard solutions and dilutions on different plating days (days 1, 4, and 7 for standard solution and the $1 / 10$ diluted solution; and days 1 and 7 for the 1/100 diluted solution). None demonstrated statistical significance. However, it is clear that the CFU are higher with longer incubation in BHI. For future studies we recommend fixing the number of days in BHI, fixing the dilution level, and the number of counting days in the Petri dish. It seems reasonable to choose the $7^{\text {th }}$ day in BHI and to observe the response on the $5^{\text {th }}$ day in the Petri dish in order to allow full opportunity for colony growth. The methodology of counting colony forming units or any quantitative isolate recovery technique should be taken into consideration when measuring responses to therapy in keratomycosis. More sensitive and specific measures are clearly needed.

Toxicity was not evaluated in our study. According to York et al., concentrations of $0.5 \%$ topical PVP-I or less ( 6 to 8 times daily) are practically non-irritating and might delay epithelial healing in one day ${ }^{(18)}$.

With the above mentioned limitations, our results do not suggest that topical $0.5 \%$ povidone-iodine is efficacious for the treatment of Fusarium solani keratitis. However, one cannot conclude from this study that the treatment modalities are equivalent. According to recently published data in the literature, topical natamycin continues to be considered the therapy of choice for treatment of filamentous keratitis ${ }^{(9)}$. Alfonso ${ }^{(19)}$ reviewed cases of Fusarium keratitis at the Bascom Palmer Eye Institute, University of Miami, in a recent contact lens related outbreak of this disease in the United States. Topical $5 \%$ natamycin was used in $91 \%$ of the patients. Newer antifungal agents such as voriconazole were promising in both in vitro susceptibility testing against ocular fungal isolates and in clinical settings ${ }^{(20)}$. However, comparative clinical trials are necessary to prove superior efficacy and safety in order to recommend voriconazole over natamycin as topical agent for Fusarium keratitis.

Using this methodology of counting colony-forming units and with this sample size, topical $0.5 \%$ povidone-iodine demonstrated no significant benefit in the treatment of experimental Fusarium solani fungal keratitis when compared with topical 5\% natamycin. It will be valuable to enlarge the sample size and to adjust the methodology in order to allow for a better evaluation of these drugs. The present study demons- 
trates important methodological considerations in the use of in vivo animal models to test the effectiveness of antifungal agents. Larger numbers and alterations in the quantitative microbiology may yet demonstrate the antifungal efficacy of these agents.

\section{RESUMO}

Objetivo: Avaliar a eficácia do uso tópico de iodo-povidona 0,5\% em ceratite experimental por Fusarium solani em coelhos. Métodos: Ceratite fúngica por Fusarium solani foi induzida no olho direito de 24 coelhos da raça New Zealand. Os coelhos foram divididos aleatoriamente em 3 diferentes grupos de tratamento: Grupo I (iodo-povidona) - tratados com iodo-povidona $0,5 \%$; Grupo II (natamicina) - tratados com natamicina 5\%; Grupo III (controle) - tratados com solução salina. Os coelhos dos 3 grupos foram tratados por 3 dias e sacrificados em seguida. As córneas foram removidas cirurgicamente, maceradas e incubadas em meio BHI. Semeou-se culturas em placas de ágar Sabouraud, diariamente, durante 7 dias, e contou-se o número de unidades formadoras de colônias (UFC). Os coelhos foram avaliados clinicamente durante o período de tratamento. Resultados: Os grupos iodo-povidona e natamicina demonstraram melhor eficácia do que o grupo controle considerando-se o número de coelhos nos quais não houve crescimento de colônias. Entretanto, não houve diferença estatística significante entre os 3 grupos quando se analizou o número de UFC ( $p>0,05$ ). Conclusão: Este estudo demonstrou considerações metodológicas importantes na utilização de modelos animais para o teste de agentes antifúngicos. Usando a metodologia de contar UFC e com este tamanho amostral, administração tópica de iodo-povidona $0,5 \%$ não demonstrou benefício do tratamento de ceratite fúngica experimental causada por $\mathrm{Fu}$ sarium solani quando comparado com a administração tópica de natamicina $5 \%$.

Descritores: Ceratite/microbiologia; Povidona-Iodo/administração \& dosagem; Povidona-Iodo/uso terapêutico; Fusarium; Natamicina/administração \& dosagem; Natamicina/uso terapêutico; Infecções oculares fúngicas/quimioterapia; Antimicóticos/administração \& dosagem; Antimicóticos/uso terapêutico.

\section{REFERENCES}

1. Foster CS. Fungal keratitis. Infect Dis Clin North Am. 1992;6(4):851-7.

2. Martin MJ, Rahman MR, Johnson GJ, Srinivasan M, Clayton YM. Mycotic keratitis: susceptibility to antiseptic agents. Int Ophthalmol. 1995-1996;19(5):299-302.

3. Thomas PA. Mycotic keratitis - an underestimated mycosis. J Med Vet Mycol. 1994;32(4):235-56

4. Sousa BL. Estudo experimental da eficácia da sulfadiazina de prata a $1 \%$ no tratamento da ceratite por Fusarium solani [tese]. São Paulo: Universidade Federal de São Paulo. Escola Paulista de Medicina; 1993.

5. Höfling-Lima AL, Forseto A, Duprat JP, Andrade A, Souza LB, Godoy P, Freitas D. Estudo laboratorial das micoses oculares e fatores associados às ceratites. Arq Bras Oftalmol. 2005;68(1):21-7.

6. Rosa RH Jr, Miller D, Alfonso EC. The changing spectrum of fungal keratitis in south Florida. Ophthalmology. 1994;101(6):1005-13.

7. Tanure MA, Cohen EJ, Sudesh S, Rapuano CJ, Laibson PR. Spectrum of fungal keratitis at Wills Eye Hospital, Philadelphia, Pennsylvania. Cornea. 2000;19(3): 307-12.

8. Prajna NV, John RK, Nirmalan PK, Lalitha P, Srinivasan M. A randomised clinical trial comparing $2 \%$ econazole and $5 \%$ natamycin for the treatment of fungal keratitis. Br J Ophthalmol. 2003;87(10):1235-7.

9. Kalavathy CM, Parmar P, Kaliamurthy J, Philip VR, Ramalingam MD, Jesudasan CA, Thomas PA. Comparison of topical itraconazole $1 \%$ with topical natamycin $5 \%$ for the treatment of filamentous fungal keratitis. Cornea. 2005;24(4):449-52.

10. Apt L, Isenberg S, Yoshimori R, Paez JH. Chemical preparation of the eye in ophthalmic surgery. III. Effect of povidone-iodine on the conjunctiva. Arch Ophthalmol. 1984;102(5):728-9.

11. Boes DA, Lindquist TD, Fritsche TR, Kalina RE. Effects of povidone-iodine chemical preparation and saline irrigation on the perilimbal flora. Ophthalmology. 1992;99(10):1569-74.

12. White JH, Stephens GM, Cinotti AA. The use of povidone-iodine for treatment of fungi in rabbit eyes. Ann Ophthalmol. 1972;4(10):855-6.

13. Fiscella RG, Moshifar M, Messick CR, Pendland SL, Chandler JW, Viana M. Polyhexamethylene biguanide (PHMB) in the treatment of experimental Fusarium keratomycosis. Cornea. 1997;16(4):447-9.

14. O'Day DM, Ray WA, Head WS, Robinson RD, Williams TE. Influence of corticosteroid on experimentally induced keratomycosis. Arch Ophthalmol. 1991; 109(11):1601-4.

15. Mitchell BM, Wilhelmus KR. Inflammatory response to fungal keratitis. Ocul Surf. 2005;3(Suppl 4):S152-3.

16. Kiryu H, Yoshida S, Suenaga Y, Asahi M. Invasion and survival of Fusarium solani in the dexamethasone-treated cornea of rabbits. J Med Vet Mycol. 1991; 29(6):395-406.

17. Sloop GD, Moreau JM, Conerly LL, Dajcs JJ, O'Callaghan RJ. Acute inflammation of the eyelid and cornea in Staphylococcus keratitis in the rabbit. Invest Ophthalmol Vis Sci. 1999;40(2):385-91.

18. York KK, Miller S, Gaster RN, Burstein NL. Polyvinylpyrrolidone iodine: corneal toxicology and epithelial healing in a rabbit model. J Ocul Pharmacol. 1988;4(4):351-8.

19. Alfonso EC, Cantu-Dibildox J, Munir WM, Miller D, O'Brien TP, Karp CL, et al. Insurgence of Fusarium keratitis associated with contact lens wear. Arch Ophthalmol. 2006;124(7):941-7. Comment in: Arch Ophthalmol. 2006;124(8): 1183-4. Comment on: Arch Ophthalmol. 2006;124(7):1051-3.

20. Marangon FB, Miller D, Giaconi JA, Alfonso EC. In vitro investigation of voriconazole susceptibility for keratitis and endophthalmitis fungal pathogens. Am J Ophthalmol. 2004;137(5):820-5. 